\title{
ワラビ精製物の構成成分について†
}

\author{
川村 美笑子*, 阿 部 捷 男 \\ 平 見 嘉 彦, 木 村 修 一** \\ 高知女子大学家政学部栄養化学 $\quad * *$ 東北大学農学部栄養化学 \\ * 現在 大阪市立大学生活科学部栄養生理
}

\section{On the Component of Purified Effective Product in Bracken}

\author{
Mieko KAWAMURA, * Katsuo ABE \\ Yoshihiko HIRAMI, Shuichi KIMURA**
}

Laboratory of Nutritional Chemistry, Kochi Women's College, Eikokuji-cho, Kochi

** Laboratory of Nutrition, Faculty of Agriculture, Tohoku University, Amamiya-cho, Sendai

* Faculty of Life Science of Living, Osaka City University

In the previous paper, a water soluble substance having protective effect for L-ascorbic acid oxidation with copper was isolated from young fronds of bracken.

This paper deals with the gel filtration of the crude effective product treated with pronase by Sepharose-6B and DEAE Sephadex A-50. Purified substance was analyzed by ultracentrifugation, electrophoresis, paper chromatography, ultraviolet spectra and elementry analysis. From these experiments, we assumed that the effective component was acidic polysaccharide including nucleic acid and its decomposition product. It was presumed that protective effect was owing to the copper chelating properties, especially the copper-base chelating than an antioxidant characteristics.

(Received February 9, 1977)

著者らは, 前報 ${ }^{12)}$ において, ワラビより L-AsA 酸化 抑制効果を有する物質を分離し, 数種の醇素処理を行な い，有効物質がいかなるるのかについて検討した。つい で，L-AsA 酸化抑制効果の低下をみないプロナーゼ処 理のものを Sepharose-6B によって精製を行なった。

今回は, さらにゲル濾過, イオン吸着クロマトグラフ イーによる精製を行ない, そのクロマト的単一のものに つき, 超遠心分析, ディスク電気泳動, 紫外線吸収スペ クトル測定, ペーパークロマトグラフィーによる検討を 行ない，その均一性および性質につき調へ，有効物は， 核酸および核酸の分解物を含み酸性糖を多く有する多糖 類ではないかと推察した。

\section{実 験 方 法}

\section{1. ゲル淲過}

Sepharose-6B (Pharmacia 40-210 $\mu$ ) のカラム (2.2 $\times 88 \mathrm{~cm})$ を $1 / 15 \mathrm{M}$ リン酸緩衝液 $(\mathrm{pH} 6.0)$ で調製し，

†銅イオン触媒による Lーアスコルビン酸酸化を抑 制する物質のワラビ中の存在について (第 3 報)

On a Protecting Factor for the Oxidation of L-Ascorbic Acid in Model Systems Associated with Pteridum aquilinum Kuhn. (No. 3)

干 780 高知市永国寺町 5-15

** 个 980 仙台市堤通雨宮町 1-1

* $\bar{T} 558$ 大阪市住吉区杉本町 459
これに試料 $29 \mathrm{mg}$ を含むりン酸緩衝液を添加し, 同緩 衝液で溶出した。溶出条件は $19 \mathrm{ml} / \mathrm{hr}$ とし， 1フラク ション $5 \mathrm{~m} l$ とした。

2. イオン吸著クロマトグラフィー

Sepharose-6B ゲル濾過より得られた有効分画をさら にDEAE Sephadex A-50により精製を行なった。有効 分画を透析し, 凍結乾燥後, $1 / 15 \mathrm{M}$ リン酸緩衝液 $(\mathrm{pH}$ 6.0)で調整したカラム $(2.1 \times 45.5 \mathrm{~cm})$ に吸着させた。 同䌐衝液 $100 \mathrm{~m} l$ でカラムを流したのち, $23 \mathrm{ml} / \mathrm{hr}$ で塩 化ナトリウムの濃度変化による溶出を行なった。さら に, $0.01 \mathrm{M}$ の塩酸および水酸化ナトリウム溶液中での 塩化ナトリウムの濃度変化による溶出を行なった。

\section{3. ペーパークロマトグラフィー}

精製した物質について，酸执よびアルカリ加水分解を 行ない,ペーパークロマトグラフィーにより検討した。 使用した試料は, DEAE Sephadex A-50 の精製より得 た白色粉末を用いた。加水分解の条件は, 次のように行 ない処理した。酸分解は, $1 \mathrm{~N}$ 塩酸および $6 \mathrm{~N}$ 塩酸を用 いたが，前者は， $50 \mu l$ 中に試料 $1 \mathrm{mg}$ を含むように調

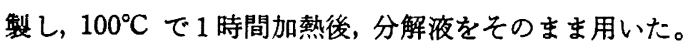
後者は, $300 \mu l$ 中に $1 \mathrm{mg}$ を含むように調製し, $\mathrm{N}_{2}$ ガ スで $\mathrm{CO}_{2}$ ガスを除き, $100^{\circ} \mathrm{C} て ゙ 3$ 時間加熱を行ない, 分解液を水酸化ナトリウム上で蒸発乾固後, $0.1 \mathrm{~N}$ 塩酸 
$50 \mu l$ に溶かして用いた。アルカリ分解は, $0.3 \mathrm{~N}$ 水酸化 カリウム溶液 $50 \mu l$ 中に $1 \mathrm{mg}$ を含むように調製し， $37^{\circ} \mathrm{C}, 18$ 時間加水分解を行ない分解液を過塩素酸で中和 し，生ずる沈澱を除きその滤液を用いた。展開溶媒は，

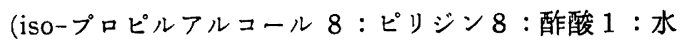
4)を用いた。

\section{4. 電気泳動}

ディスク電気泳動は， $6.0 \times 70 \mathrm{~mm}$ のガラス管を使用 した。試料は, $0.1 \mathrm{M}$ ショ糖を含むトリスーグリシン緩衝 液に $0.5 \%$ 濃度に溶かしたるのを使用した。この溶液 $25 \mu l(100 \gamma)$ を添加し，泳動したものが Fig. 6. であ る。アクリルアミドゲルは, $3.5 \%$ のポリアクリルアミ ドを用い，泳動は，トリスーグリシン緩衙液（トリスア ミノメタン $6.0 \mathrm{~g}$, グリシン $28.8 \mathrm{~g}$, 水 $1 l, \mathrm{pH} 8.6$ ) 中で 1 時間 30 分行ない, 定電王 $200 \mathrm{~V}$ で行なった。

\section{5. 分析法}

精製された物質につき，紫外の吸収スペクトルを測定 し，また超遠心分析，元素分析等を測定した。

\section{実 験 結 果}

\section{1. ゲル滤過}

前報に就いて，有効物をプロナーゼ処理し，さらに，

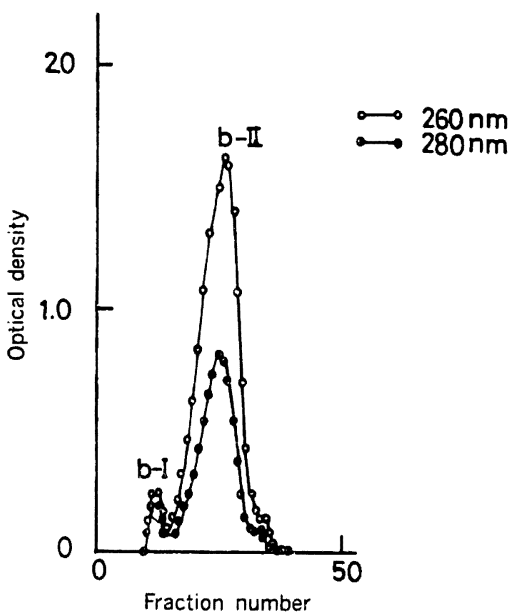

Fig. 1. Elution profiles of product I treated with pronase after twice gel filtration by Sepharose-6B.

Gel filtration of product I treated with pronase on a sepharose-6B column $(2.2 \times 88 \mathrm{~cm})$. The sample was prepared from approximately $29 \mathrm{mg}$ was applied to the column equilibrated with $1 /$ $15 \mathrm{M}$ phosphate buffer ( $\mathrm{pH} 6.0$ ). The column was eluted with the same solution at a flow rate of $19 \mathrm{ml} / \mathrm{hr}$ at $25^{\circ} \mathrm{C}$. Fraction of $5 \mathrm{ml}$ were collected and absorbance was read at $260 \mathrm{~nm}$ and $280 \mathrm{~nm}$. Aliquots of $3 \mathrm{ml}$ were used to determine the activity.
Sepharose-6B カラムによる精製を行なった。これより得

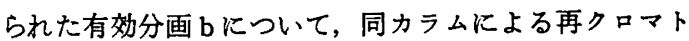
を行ない。Fig. 1 に示すよらなバターンを得た。L-AsA 酸化抑制効果はb-II にのみあり,クロマト的にほぼ単 一なピークが得られた。

\section{2. イオン吸前クロマトグラフィー}

Sepharose-6Bによる再クロマトより得た有効分画 bII について, さらに, DEAE Sephadex A-50 による 精製を試みた。塩化ナトリウムの濃度变化による溶出を 行なった。その溶出曲線は Fig. 2 に示すようである。 すなわち, 分画 1 ～8が得られたが， L-AsA 酸化抑制 効果は分画 2 のあった。

酵素処理, ゲル滤過, イオン吸着クロマトグラフィー による精製過程を Table 1 に示す。また, 分画 2 のク ロマト的に単一な有効物につき超遠心分析を行ない。 Fig. 3 に示す。元素分析値は, 炭素 $2.46 \%$, 水素 2.25 $\%$ ，窒素 $0.77 \%$ であった。

3. ペーパークロマトグラフィー

Fig. 4 に示すように分画 2 は紫外線吸収がえられ, またアルカリ性硝酸銀試薬，ドラーゲンドルフ試薬，八 ンス試薬による発色がみられた。な拈、ニンヒドリン試 薬による発色は認められなかった。

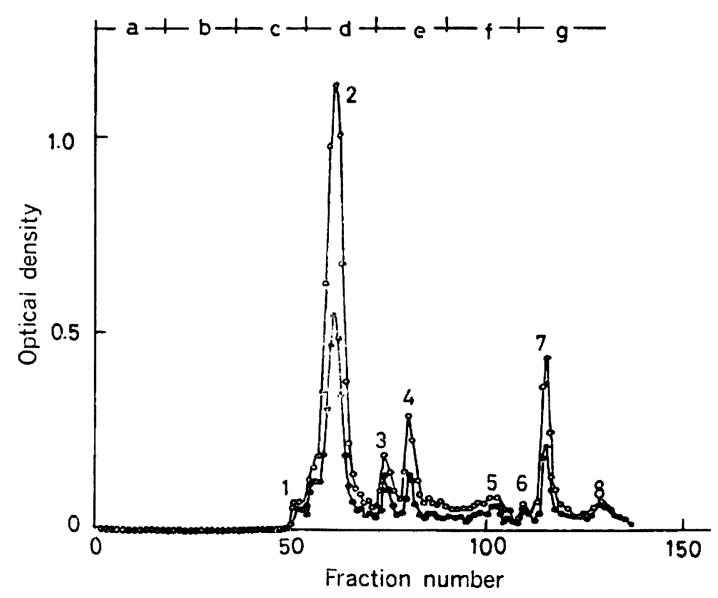

Fig. 2. Chromatography of the fraction b-II with DEAE Sephadex A-50.

The fraction b-II (70 mg) obtained after Sepharose-6B gel filtration was chromatographed on the DEAE Sephadex A-50 column. Elution was performed with stepwise of $\mathrm{NaCl}$ as shown. Fraction of $5 \mathrm{ml}$ were collected and absorbance was read at $260 \mathrm{~nm}$ and $280 \mathrm{~nm}$.

a : $1 / 15 \mathrm{M}$ phosphate buffer $(\mathrm{pH} 6.0), \mathrm{b}: 0.5 \mathrm{M}$ $\mathrm{NaCl}$ in a, c: $1.5 \mathrm{M} \mathrm{NaCl}$ in a, d: $2.5 \mathrm{M} \mathrm{NaCl}$ in a, e: $0.5 \mathrm{M} \mathrm{NaCl}$ in $0.01 \mathrm{M} \mathrm{NaHO}, \mathrm{f}: 1.5 \mathrm{M}$ $\mathrm{NaCl}$ in $0.01 \mathrm{M} \mathrm{NaOH}, g: 2.5 \mathrm{M} \mathrm{NaCl}$ in $0.01 \mathrm{M}$ $\mathrm{NaOH}$. 
Table 1. Purification of product I from Pteridum aquilinum Kuhn.

\begin{tabular}{lcccc}
\hline \multicolumn{1}{c}{ Sample } & Volume $(\mathrm{g})$ & $\mathrm{A}_{280} / \mathrm{A}_{260}$ & \multicolumn{2}{c}{ Dry yield $(\%)$} \\
\hline Raw sample & 15.789 & - & 100 (raw) & - \\
Dry sample & 1.579 & - & 10 & 100 \\
Crude extract & 0.100 & 0.84 & 0.6 & 6.3 \\
Treated with pronase, dialysis and freeze drying & 0.057 & 0.79 & 0.4 & 3.6 \\
Sepharose-6B & 0.029 & 0.54 & 0.2 & 1.8 \\
re Sepharose-6B & 0.015 & 0.51 & 0.1 & 1.0 \\
DEAE Sephadex A-50 & 0.012 & 0.49 & 0.1 & 1.0 \\
\hline \hline
\end{tabular}

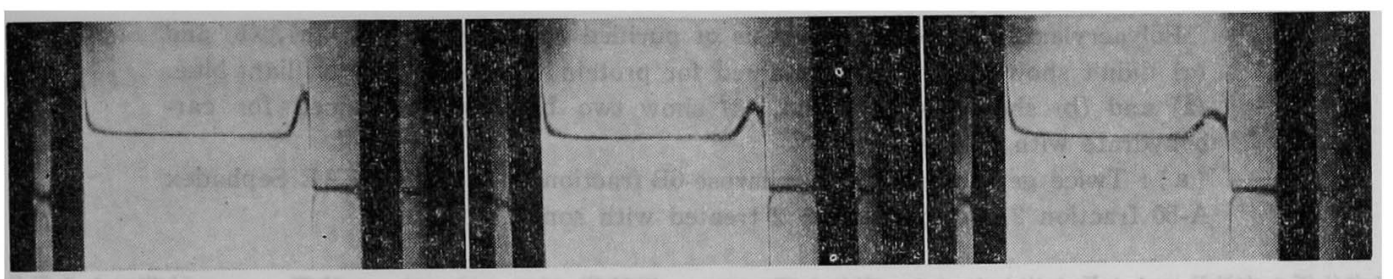

Fig. 3. Sedimentation pattern of purified product I.

The direction of sedimentation is from left to right. Photographs are shown at 16, 25 and $34 \mathrm{~min}$ after attaining a speed of $55,430 \mathrm{rpm}$. The concentration (Purified product I) was $6.2 \mathrm{mg}$ per $\mathrm{m} l$ in phosphate buffer $(\mathrm{pH} 6.0)$. The temperature was $10.2^{\circ} \mathrm{C}$.

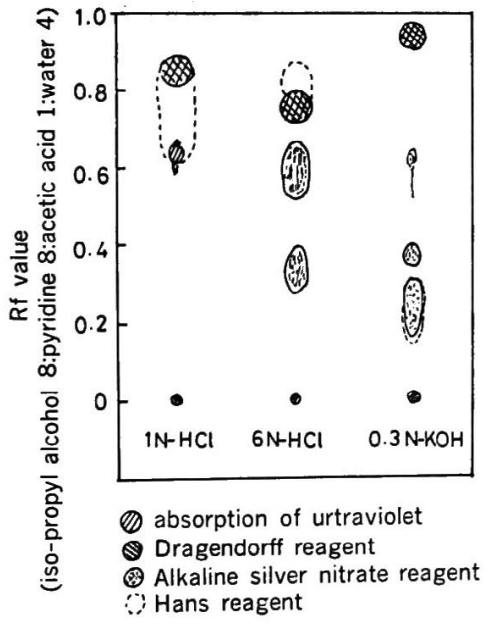

Fig. 4. Paper chromatograms of hidrolytic fraction 2 (DEAE Sephadex A-50).

Hydrolysis was carried out as follows. DEAE Sephadex A-50 fraction 2 was heated for 1 hour at $100^{\circ} \mathrm{C}$ in respectively $\mathrm{N}-\mathrm{HCl}$ and $6 \mathrm{~N}-\mathrm{HCl}$, for 18 hours at $37^{\circ} \mathrm{C}$ in $0.3 \mathrm{~N}-\mathrm{KOH}$.

\section{4. 紫外吸収スペクトル}

Fig. 5 K, 粗有效抽出物, その最終精製物括よび加 水分解後のペーパークロマトグラフィーより得られた紫 外吸収部のスペクトルを示す。ペーパー上り水で溶出し た紫外吸収部のスペクトルは，ポリヌクレオテドの塩基

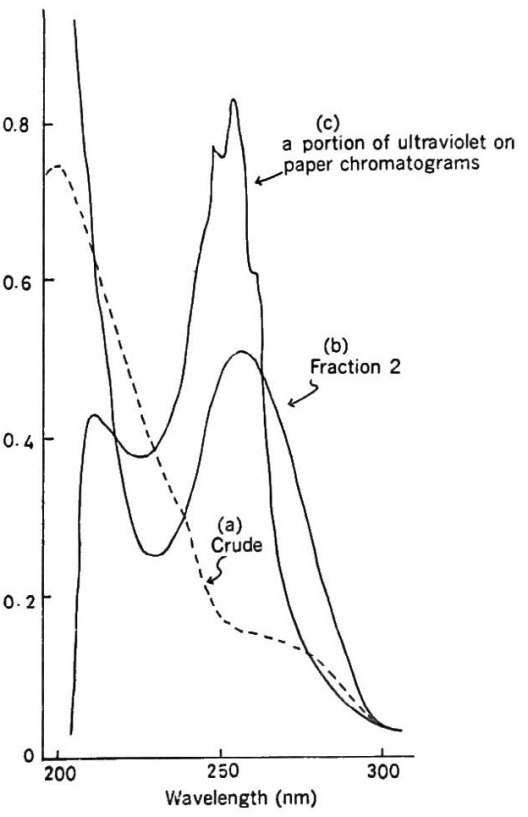

Fig. 5. The absorption spectrum of effective product I.

(a): Product I, (b) : DEAE Sephadex A-50 fraction 2, (c): Eluants of ultraviolet absorption on paper chromatogiams. 

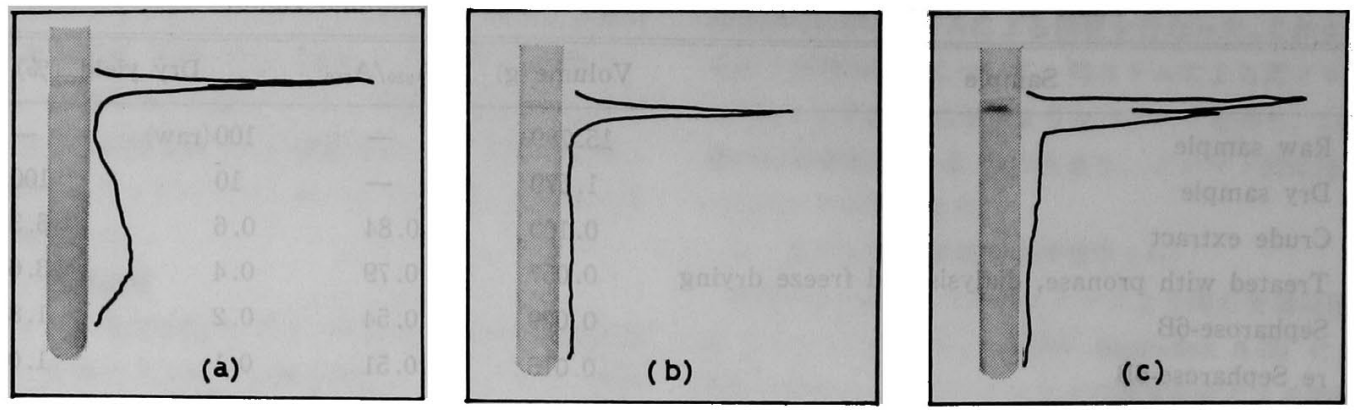

Fig. 6. Disc gel electrophoretic patterns and densitometric scan of purified effective product $\mathrm{I}$.

Polyacrylamide gel electrophoresis of purified effective product. (a), (b) and

(c) didn't show a band when stained for protein with coomossie brilliant blue.

(a) and (b) show a single band, (c) show two band when stained for carbohydrate with pas reagent.

(a) : Twice gel filtration by Sepharose-6B fraction b-II, (b) : DEAE Sephadex

A-50 fraction 2, (c) : Fraction 2 treated with sonic.

組成分析の方法 あった。また，このプリン画分には L-AsA 酸化抑制効 果がみられ, ピリミジン分画部には, 効果はみられなか っだ)。

\section{5. ディスク電気泳動}

Fig. 6 は ( I ) 再 Sepharose-6B, (II) DEAE Sephadex A-50 および (III) DEAE Sephadex A-50 処理後のも のを超音波処理したものの, 電気泳動パターン拈よび泳 動図を示す。電気泳動バンドは, ( I ) は二つであり,さ らに精製された（II）は一つである。しかし，（II）を超音 波処理した(III) は2 バンドを示した。

\section{考察}

前報において得られたところの, Sepharose-6B カラ ムによる精製物を, さらに, 同カラムにより再クロマト を行ない,クロマト的に単一なるのを得た。しかしなが ら, 電気泳動に打いては, PAS 試菜による二つの染色 バンドがみられたことや，超遠心分析から推察して単一 と思われないので, さらに, DEAE·Sephadex A-50 による精製を試みた。このイオン吸着クロマトグラフィ

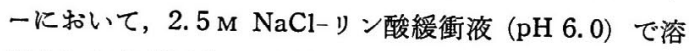
出された有効画分は, 電気泳動に扎いても一つのバンド を示し，超遠心分析からも均一なるのと考穴られる。

一般に, 核酸を加水分解すると, DNA は, 酸分解 $(6 \mathrm{~N}-\mathrm{HCl})$ により塩基になで, RNA は, 酸分解 (1N$\mathrm{HCl})$ によってプリン塩基とピリミシンモノヌクレオチ ドにまで，あるいは，アルカリ分解 $(0.3 \mathrm{~N}-\mathrm{KOH})$ によ つてすべてをモノヌクレオチドにまで分解される。均一 之思われる有効物を, 同条件で加水分解を行なった物の ペーパークロマトグラフィーの結果は, アルカリ性硝酸
銀試薬,ドラーゲンドルフ試薬, ハンス試薬による発色を 示し, おのおの, 還元糖, $\mathrm{N}$ を含む化合物, $\mathrm{P}$ を含む化合 物の存在が予想される。また，いずれの場合にも，紫外 線検出器により，展開ペーパー上に黒いquenching spot が検出され，プリン，ピリミジン塩基はもちろん，ヌク レオシド，ヌクレオチド等の存在が推測される。

精製された有效画分は, $257 \mathrm{~nm}$ 付近に持性四収をる ち, 類似の吸収をもつ quenching spot の溶出液は, ポ リヌクレオチドの塩基組成分析の方法によって得たプリ ン分画と一致し, 一部は, ペントース発色と重なった。

前報および，以上の結果を総合すると，精製された有 効物は，核酸あるいはその分解物を含む酸性糖を主とし た化合物であるらと思われる。Duncan ${ }^{5)}$ は，ワラビの 根において, ヌクレオチドの $80 \%$ はウリジン誘導体で あり, 残りの $12 \%$ はグフノシン, $8 \%$ はアデノシン化 合物であると報告している。また，Jarris ${ }^{6)}$ は，根と若 い葉より, 水溶性の酸性多桾類の存在を確認している。 従来, アスコルビン酸酸化抑制物質として，千才尿素， リン酸塩, 食塩, アミノ酸, 糖類, デンプン, ゼラチ ン, アラビアゴム, ペクチン等が知られているが，今回 のワラビの精製された有効物の酸化抑制作用は，その構 成成分として含まれると推測される核酸および核酸関連 化合物質と $\mathrm{Cu}^{2+}$ 錯体形成，とくに，塩基との $\mathrm{Cu}^{2+}$ 錯 体に起因するものと考只られる。しかしながら，ほかの 構成成分，たと点ば，酸性多糖類のような物質との相乗 効果等に関しては, 明らかではなく, 今後の検討を必要 とする。

要 約

前報より,ひき続いて精製を行ない，次の結果を得 
た。

1. Sepharose-6B による再クロマトDEAE Sephadex A-50 による精製を行ない，クロマト的に単一な有効物 を得る。

2. この精製物は，超遠心的・ディスク電気泳動的に は均一であり，ペーパークロマトクラフィーにより検討 した結果，核酸あるいはその分解物を含む酸性糖を主と した多糖の可能性であることが示された。

最後に, 本研究を行ならにあたり機器測定の労をとら れた東北大学農学部菊地愛子氏, 高原英成氏, 同薬学部 堀江孝氏に感謝します。

本報告の一部は, 日本ビタミン学会第 28 回大会（仙 台，昭和51年 4 月24日）において発表した。
文献

1）川村美笑子, 阿部捷男, 平見嘉彦: 栄養と食糧, 30, 395 (1977)

2）川村美笑子, 阿部捷男, 平見嘉彦, 木村修一：栄 養と食糧, 30，399（1977）

3）日本化学会編 : 実験化学講座 23 , 生物化学 I, 327 (1957)

4) 第29回日本ビタミン学会 (昭 52.6.3. 京都) 口頭 発表

5) Duncan, H.J. : J. Sci. Fd Agric., 25, 211 (1974)

6) Michael, C. Jarris and Duncan, H. J.: Phytochemistry, 15, 171 (1976)

(昭和 52 年 2 月 9 日受理) 